\title{
Koşulsuz Müşteri Memnuniyeti Uygulamalarının Uluslararası Muhasebe/Finansal Raporlama Standartları (UMS/UFRS) Açısından Değerlendirilmesi
}

\author{
DOI: 10.26466/opus.584091 \\ * \\ $\underline{\text { Vedat Acar* }}$ \\ * Doç. Dr, İzmir Bakırçay Üniversitesi, İ.̇̇.B.F, Menemen / İzmir / Türkiye \\ E-Posta: vedat.acar@bakircay.edu.tr ORCID: 0000-0002-5681-0200
}

Öz

Küresel ekonominin gereklerinden olan rekabetin boyutları hızla artmaktadır. Bunun doğal bir sonucu olarak da işletme yöneticileri tarafindan, fiyatlar üzerinden yapılan savaşların yerini alacak yeni araçlar geliştirilmeye çalışılmaktadır. Marka imajını geliştiren ve talebin fiyat esnekliğini kıran büyük işletmelerin, müşterilerinin önüne koyacakları başka tatmin araçlarına ihtiyacı bulunmaktadır. Müşteriler benzerlerinden nispeten pahalı olan markalara yöneltilirken, onların ileride üründen kaynaklanabilecek sorunlarının da hızh ve istenilen şekilde çözümü konusunda rahatlatılması, satış arttırma çabalarına da önemli katkılar sağlayabilecektir. Ürünlerde müşteriden kaynaklanan herhangi bir sorun olması durumunda dahi değişim garantisi, müşterinin neden pahalı bir ürünü aldığııı kendisine kabul ettirebilmesi konusunda da önemli bir işlev görmektedir. "Koşulsuz Müşteri Memnuniyeti" ürün garantisinin çok daha genişletilmiş bir hali olarak görülebilir. Bu nedenle koşulsuz müşteri memnuniyeti uygulamalarından doğan giderler konusunun, Uluslararası Muhasebe/Finansal Raporlama Standartlarn (UMS/UFRS) ile Türkiye Muhasebe/Finansal Muhasebe Standartlarn (TMS/TFRS) açısından değerlendirilmesi önemlidir. Bu çalışmada Koşulsuz Müşteri Memnuniyeti kavramı ile bu kavramın işletmeler arasındaki farklı uygulama şekillerine değinilecek, UMS/UFRS ve TMS/TFRS perspektifinde, bu uygulamaların işletmeye getirmiş olduğu yüklerin nasıl kaydedilmesi ve raporlanması gerektiği üzerinde durulacaktır.

Anahtar Kelimeler: Koşulsuz müşteri memnuniyeti, Müşteri memnuniyeti garantisi, Uluslararası muhasebe standartlarl, Muhasebe 


\title{
Evaluation of Unconditional Customer Satisfaction Practices In Terms Of International Accounting / Financial Reporting Standards (IAS / IFRS)
}

\begin{abstract}
The dimensions of competition, one of the requirements of the global economy, are increasing rapidly. As a natural consequence of this situation, new tools are being developed by the business managers to replace the wars over the prices. Large enterprises that improve brand image and break price elasticity of demand need other satisfaction tools to put in front of their customers. While customers are directed to brands that are relatively expensive from their similar, relieving the problems that may arise in the future in a fast and desirable way can also significantly contribute to the efforts to increase sales. In case of any problems in the product that are caused by the customer, the guarantee of change also plays an important role in enabling the customer to accept why he/she is purchasing an expensive product. Unconditional Customer Satisfaction seen as a much more extended version of the product warranty. Therefore, the evaluation of the issue of expenditures arising from the applications of unconditional customer satisfaction is important in terms of the International Accounting/Financial Reporting Standards (IAS/IFRS) and Turkish Accounting/Financial Accounting Standards (TMS/TFRS). In this study, the concept of Unconditional Customer Satisfaction and the different applications of this concept among enterprises will be mentioned and then will be focused on how to record and report the costs of these applications in the perspective of IAS/IFRS and TMS/ TFRS.
\end{abstract}

Keywords: Unconditional customer satisfaction, Customer satisfaction guarantee, International accounting standards, Accounting 


\section{Giriş}

Küresel ekonominin gereklerinden olan rekabetin boyutları hızla artmaktadır. Bunun doğal bir sonucu olarak da işletme yöneticileri tarafından, fiyatlar üzerinden yapılan savaşların yerini alacak yeni araçlar geliştirilmeye çalışılmaktadır. Marka imajını geliştiren ve fiyat esnekliğini kıran büyük işletmelerin, müşterilerinin önüne koyabilecekleri başka tatmin araçlarına ihtiyacı bulunmaktadır. Müşteriler kıyaslama yaptıklarında nispeten pahalı olan markalara yöneldiğinde, gelecekte üründen kaynaklanabilecek sorunların da hızlı ve arzu ettikleri şekilde çözümünü beklemektedir. Bu kapsamda müşterilere, kendilerinden kaynaklanan herhangi bir sorun olması durumunda dahi değişim garantisi verilmesi, satış arttırma konusunda da önemli katkılar sağlamaktadır.

Değişim garantisinin çok daha genişletilmiş bir hali olarak görebileceğimiz "Koşulsuz Müşteri Memnuniyeti” uygulamaları acaba gerçekten koşulsuz mudur? Ya da nereye kadar koşulsuzdur? Bütün bu sorular, internet siteleri de dahil olmak üzere, her ortamda koşulsuz müşteri memnuniyeti uygulamaların ilke edindiklerini iddia eden işletmelerde tam olarak cevaplanamamaktadır. Tıpkı otel işletmelerinde "her şey dahil", "ultra her şey dahil" vb. çeşitlendirmelerle farklılaşmaya gidilmesinde olduğu gibi. İşletmelerin sadece müşterilerini mutlu etmek değil, bunun yanında hissedarlarını mutlu etmek gibi bir görevlerinin de olduğu hatırlandığında, "koşulsuz" ifadesinin sınırlarının çizildiği ya da çizilmek zorunda kalınacağı da aşikâr olmaktadır.

Alacağ 1 ürünün hem ucuz hem de yıllarca kendisine hizmet etmesini ve bozulduğunda da en kısa sürede arızanın giderilmesini bekleyen bir müşteriyi koşulsuz memnun edebilmek mümkün müdür? Bu durumda gerçekleşecek maliyeti, yani "koşulsuz müşteri memnuniyeti" bedelini kim ve ne zaman ödeyecek? Bu sorulara cevap verilirken muhasebenin genel kabul görmüş ilke ve kuralları ile ulusal ve uluslararası muhasebe standartlarının da bakış açısı değerlendirilmek zorundadır.

Aşağıda öncelikle Türkiye ve Dünyada çeşitli şekillerde uygulanmakta olan koşulsuz müşteri memnuniyeti uygulamaları gerek kapsam ve gerekse içerik yönünden incelenmektedir. Bu bağlamda uygulamalardan doğan maliyetlerin niteliği tespit edilerek, işletmelerin gerçek faaliyet so- 
nuçlarının ve finansal durumunun ortaya konulması ile finansal tabloların dönemler arasında karşılaştırılabilir olması ilkesinin zarar görmemesi amacıyla, yapılması gereken muhasebe uygulamaları ortaya konulmaktadır. Bu bağlamda ilgili uygulamalar ulusal ve uluslararası muhasebe standartlarının bakış açısıyla da değerlendirilmektedir.

660 sayılı Kanun Hükmünde Kararname ile 2 Kasım 2011 tarihinde kurulan, Kamu Gözetim Kurumu Muhasebe ve Denetim Standartları Kurumu (KGK), Uluslararası Muhasebe Standartları (UMS) ve Uluslararası Finansal Raporlama Standartları (UFRS) ile uyumlu Türkiye Muhasebe Standartlarını (TMS) ve dolayısıyla Türkiye Finansal Raporlama Standartlarını (TFRS) oluşturmak ve yayımlamak amaç ve yetkisine sahip, idari özerk bir üst kuruldur (KGK, 2019a).

KGK tarafından oluşturulan ve yayımlanan TMS/TFRS'ler, IASB (International Accounting Standard Board) tarafından yayımlanan UMS/UFRS'lerin birebir Türkçe tercümeleridir. 2001 yılından sonra yayımlanan UMS'ler, "IAS" (International Accounting Standard-Uluslararası Muhasebe Standardı) yerine "IFRS" (International Financial Reporting Standards-Uluslararası Finansal Raporlama Standartları) adını almıştır. Bu kapsamda TMS'ler IAS'lerin; TFRS'ler ise IFRS'lerin birebir Türkçe çevirilerini ifade etmekte olup, TMS'ler ve TFRS'ler arasında bağlayıcılık açısından bir farklılık da bulunmamaktadır (KGK, 2019b). Bu nedenle bu çalışma kapsamında takip eden ifade ve açıklamalarda, kavram karmaşasına sebep olmamak açısından UMS ve UFRS ifadeleri kullanılmamış, KGK tarafından da ifade edildiği üzere, bunların bire bir Türkçe tercümesi olduğu için TMS ve TFRS ifadeleri kullanılmıştır.

\section{Koşulsuz Müşteri Memnuniyeti}

\section{Koşulsuz Müşteri Memnuniyeti Kavramı}

Mükemmel veya kusursuz yönetilen işletmelerin ortak özelliklerini belirlemeye yönelik olarak 1980'lerde ABD'de yapılan araştırmalar, "müşteriye yakınlık" ve bu çerçevede müşterilerini iyi tanıma, pazarlarını iyi tanımlama, tüketici tatminini hep ön planda tutarak, müşteriye daha kaliteli mal, hizmet ve güvenilirlik sunma ve personelini bu yönde motive etme 
gibi, bazı temel pazarlama ilkelerinin uygulanmasına önem verilmesi olduğunu ortaya koymuştur (Mucuk, 1999, s.2). Bu bağlamda müşteri sadece bir bilgi kaynağı değil, kullandığı ürünlerin satışlarını olumlu veya olumsuz anlamda etkileyen kişidir (Gürsakal, 2005, s.69-70). Örneğin Türkiye'de orta gelir düzeyi ve üzerinde olan bir müşterinin yaşamı boyunca toplam dört kez bir buzdolabı satın alabileceğini düşünürsek, satın almış olduğu A marka buzdolabından memnun olmaması, bunu çevresinde kendisine benzer 30 kişiye iletmesi ve bunlardan beşi üzerinde etkili olması halinde, A marka buzdolabı üreticisinin kaybı dört adet değil, 24 adet buzdolabı satış kaybı olacaktır. Dolayısıyla müşteri memnuniyeti, müşterilerin kuruluş ile iş yapma süresini uzatmakta ve bu süre içinde müşterinin satın alması ile oluşan net değerini arttırmaktadır. Çünkü araştırmalar, mutsuz müşterilerin \%94'ünün şikâyetini dile getirmek üzere işletmelere başvurmak için çaba sarf etmediğini, bunun yerine işletmeyi terk ederek rakip işletmelere başvurduğunu ve mutsuzluklarını diğer potansiyel müşterilerle paylaşarak, işletmenin müşteri kaybetmesine neden olduğunu göstermektedir (Şahin ve Şen, 2017, s.1178).

İşletmeler tarafından üretilen mal ve hizmeti satın alan ya da satın alma potansiyeli olan kişi ve kuruluşlar olan müşterilerin hangilerinin daha önemli olduğuna karar vermek çok doğru bir yaklaşım olmamaktadır. Çünkü yoğun ve küresel rekabet, işletmeleri hem ürününü satın almış olan müşterilerini elinde tutmak, hem de potansiyel müşterileri mümkün olduğunca kazanmak üzerine strateji izlemelerini zorunlu hale getirmektedir. Bu bakış açısıyla, müşterilerin üründen olan beklentilerinin karşılanması olarak ifade edebileceğimiz müşteri memnuniyeti, halihazırdaki müşterilerin elde tutulması için yeterli olarak görülebilir. Ancak yeni müşterilerin kazanılması sürecinde bunun bir adım ötesi olan koşulsuz müşteri memnuniyeti daha etkili olacaktır.

Günümüz işletmelerinin odaklandığı temel nokta, rasyonellik ve verimlilik sağlayarak, maksimum çıktı elde etmek temel hedefi olan geleneksel bakış açlarından farklı olarak, "koşulsuz müşteri memnuniyeti" sağlamaktır (Doğan ve Demiral, 2007, s.283). Bu bağlamda koşulsuz müşteri memnuniyetinde, sürekli gelişim, süreç yönetimi ve sistem yaklaşımı gibi ilkeler doğrultusunda önemli bir yaklaşım olan müşteri memnuniyeti ilkesi ile hareket edilmekte ve mevcut müşteri kitlesini koruyarak sadık 
müşterilerini yaratmak ve her geçen gün portföyünü geliştirmek için, hizmetleri ve altyapısı ile tüketicisinin karşısına çıkmaktadır (Sakallı, 2007, s.50). Bu noktada sıklıkla karşımıza çıkan bir kavram olan müşteri ilişkileri yönetimi (CRM), müşteri odaklılık, genellikle koşulsuz müşteri memnuniyeti kavramı ile bir arada kullanılan önemli pazarlama kavramları arasındadır. Müşteriler hakkında olabilecek en detaylı bilgileri elde edip, onları birey olarak tanımlamak ve ortak özelliklerine göre segmentlere ayırarak, onlara bu bilgiler ışığında ürün ve hizmet sunmak şeklindeki süreç pazarlama dünyasına damgasını vuran CRM'in hareket noktasının, tüketici istek ve ihtiyaçlarının oluşturduğu ve ulaşılmak istenen hedeflerin öncelikle koşulsuz müşteri memnuniyeti ve sadakati olan bu pazarlama yaklaşımının, bilgi ve insanı merkeze taşıdığı ifade edilmektedir (Özilhan, 2010, s.19). Bu çerçevede ele alınabilecek bir diğer kavram olan müşteri odaklılıkta ise en genel ve özet ifadeyle, çağrı merkezinde beklemeden hizmet alınması, indirimlerden önceden haberdar edilmesi, fazladan taksit yapılması, kendisine özel müşteri atanması gibi hizmet seviyesinin farklılaştırılma uygulamaları şeklinde, başka bir ifadeyle koşulsuz müşteri mutluluğu değil, müşteriye hak ettiği hizmet seviyesini sunmaktır ve CRM'de olduğu gibi müşterinin neyi hak ettiğinin ölçüsü de yaşam boyu değeridir (Özmen, 2019).

CRM ya da müşteri odaklılıkta, müşterilere eşit değerde bakılmamakta, işletme ile olan ilişkisinin devamı süresince, işletmeye kar sağlıyorsa diğerlerinden ayrıştırılmasına ve daha fazla ilgi gösterilmesine çalış1lmaktadır. Bu konuda çalışma yapan Triest vd., (2009, s.125), müşteriye özel yapılan pazarlama giderlerinin, müşteriyi elde tutma ve karlılığı üzerindeki etkilerini incelemişlerdir. Çalışmanın sonucunda; bu tür giderlerin müşteri gelişiminden ziyade, daha fazla karlılık sağlayan büyük müşteriyi elde tutmaya katkı sağlayan bir araç olduğunu ve küçük müşteriler üzerinde de önemli bir etkisinin olmadığını tespit etmişlerdir. Benzer sonuçları Homburg vd., (2008, s.110), 310 işletme üzerinde yapmış oldukları ampirik bir çalışmada teyit etmektedirler. Bu çalışmada; işletmelerin çabalarının en önemli müşterilere odaklanmasının ve onları önceliklendirmesinin daha yüksek ortalama müşteri karlılığını ve satışlarda da daha yüksek getiri sağladığını, bu politikadan üst düzey müşterilerin olumlu etkilenmesine karşılık, alt düzeyde kabul edilen, başka bir ifadeyle daha 
az önemli müşterilerde bir etki yaratmadığını, ayrıca pazarlama ve satış giderlerini de azaltıcı yönde etkide bulunduğunu ortaya koymuşlardır.

Koşulsuz müşteri memnuniyeti ise müşteri odaklılık ve CRM gibi kavramlardan farklı olarak, işletmeye katkısı dikkate alınmaksızın tüm müşterilere eşit değer verilmesini ve hatta kullandıktan yıllar sonra bile ürünü değiştirmek isteyen müşteriye de aynı hassasiyetin gösterilmesini ve memnuniyetinin devam ettirilmesini gerekli kılmaktadır. Bu bağlamda bir hayal olmaktan öte, başarılması gereken bir hedef olan koşulsuz müşteri memnuniyetini başarmak için, işletmenin insan kaynağını çalışanlardan ve müşterilerden oluşmuş bir bütün olarak algılamak gerekmektedir. Bu düşünceye göre müşteri, mevcut hizmet sisteminin en büyük artı değerini sağlamakta, işletmeden alışveriş yapan yabancı biri olmaktan çıkarak, hizmet sisteminin bir parçası haline gelmektedir (Alnıaçık ve Özbek, 2009, s.127).

\section{Dünyada Koşulsuz Müşteri Memnuniyeti Uygulamalan}

Savaş sonrası Japonya'nın yeniden inşasına dayanarak Deming ve Juran tarafından açıklanan örgütsel gelişim stratejileri, nihai hedefi müşteri memnuniyeti olan toplam kalite yönetimi felsefesini ve stratejisini bir yönetim stratejisi olarak geliştirmiştir (Alomaim vd., 2003:666). Bu noktada özellikle dayanıklı tüketim mallarında uzun yıllardır uygulanagelen servis garantileri olarak adlandırılan hizmetler, ürün garantilerinin genişletilmiş bir şeklidir ve tüketiciye ürün arızasına karşı koruma sağlayarak riskini azaltır ve satın alma kararına olan güveni arttırır (McDougal, 1998, s.278-279).

Ürün garantileri, genellikle kapsam, süre ve ödeme bakımından kısıtlanmış olmasına karşılık, birçok hizmet garantisi aynı açılardan hiçbir şart içermeyecek şekilde koşulsuz olabilmektedir. Koşulsuz bir garanti, hem temel hizmet teklifini (örneğin bir otel odası, yemek, saç kesimi) hem de hizmetin teslimini (örneğin kibar, güler yüzlü hizmet işgörenleri) kapsadığından hareketle, son birkaç yıl içinde artan sayıda hizmet işletmesi, müşterilerin güvenilirlik algılarını etkilemenin en etkili yollarından birinin, koşulsuz bir memnuniyet garantisi sunmak olduğunu keşfetmiştir (McDougal, 1998, s.279). 
Wall Street Journal Europe sadece 2000-2001 yılları arasinda toplam 555 internet şirketinin kapatıldığını ifade etmektedir (Alomaim vd., 2003, s.666). Aboelmaged ve Tunca çalışmalarında, birçok sanal organizasyonda olduğu gibi internet şirketlerinin de sadece finansal sorunlarla karşı karşıya kalmadığını, ayrıca potansiyel krizleri içeren iç ve dış tehditlerle de karşı karşıya kaldıklarını vurgulamaktadır. Bu bağlamda sanal organizasyonlardaki dönüşüm sürecinde, tüketiciler talebin işlendiği işlemlerin ana girdisi olmakta, çıktı olarak ise memnun müşteri yaratılmaktadır. Bu nedenle memnun bir müşteri, başarılı bir internet şirketi için anahtar faktör olmaktadır (Alomaim vd., 2003, s.666).

Koşulsuz müşteri memnuniyet garantisi ifadesi, uluslararası alanda koşulsuz müşteri memnuniyeti ifadesinden daha fazla kullanılan bir kavram olarak karşımıza çıkmaktadır. Bu bağlamda bir işletmenin müşterilerine iletebileceği mesajlardan en güçlü olanının, koşulsuz bir memnuniyet garantisi olduğu ve bu ifadenin barındırdığı mesajın; koşulsuz ifadesiyle mazeret ya da açıklama istenmeyeceği, memnuniyet ifadesiyle de müşterinin bir şirketin doğru yaptığı ya da yapmadığ şeylerin son hakemi olduğu anlamına gelen kilit noktalarını belirttiği ifade edilmektedir. Diğer bir ifadeyle koşulsuz bir garanti, bir işletmenin tüm müşterilerinin beklentilerini karşılayacağına dair verdiği sözdür (Swartz ve Lacobucci, 2000, s.305).

Koşulsuz memnuniyet garantisi, müşterilere tam memnuniyet ya da tercih etmeleri halinde paralarını geri verme sözü de vermektedir. Koşulsuz bir garanti, örneğin bir konaklama hizmet işletmesinin müşterisine sunduğu tekliflerinin bütününe güven konusunda, aşağıda belirtilen unsurları içerecek şekilde güçlü bir açıklama sağlar (Bowie ve Buttle, 2004, s.287);

- Memnun kalınmadığında, yüzde yüz geri ödeme yapılabileceğinin bilincinde olan müşteriye hizmeti satın alma konusunda güven verme,

- İşletmenin sözünü yerine getirme ya da bir hizmet garantisi vermeyeceği güvencesi,

- Benzer bir garanti vermeyen rakiplere göre tercih edilme.

Hizmet sektörü özelinde birçok işletme yöneticisi tarafından verilmesinin mümkün olmayacağı konusunda bir inancın hakim olduğu koşulsuz müşteri memnuniyeti garantisinin, daha çok ürünler için kullanılabileceği 
düşünülebilir. Çünkü bozulan bir televizyonun tamir için fabrikaya gönderilmesi veya yenisi ile değiştirilmesi halinde müşteri memnuniyetinin sağlanması mümkündür. Ancak kötü bir otelde balayı tatilini geçiren bir çift ya da düğün fotoğraflarının bozulmasına neden olan bir hatanın telafisi nasıl sağlanacak ve müşteri nasıl tatmin edilecektir? En önemlisi de bu hizmetleri sunan hizmet sağlayıcısı işletmeler, hizmet satışı öncesi koşulsuz memnuniyet garantisini nasıl verecektir? Kuşkusuz bu uç örnekler cevabı olumsuz hale getirse de tüm hizmetler için memnuniyet garantisinin verilmeyeceği sonucunu doğurmaz (Hart, 1988). Örneğin, ABD merkezli bir haşere imha işletmesi tarafından sunulan garantide; işletmenin rakiplerinin çoğu zararlıları "kabul edilebilir seviyelere" düşüreceklerini iddia ederken, ilgili işletme onları tamamen yok etmeyi vaat etmektedir. Hatta bu garantinin kapsamı o kadar geniştir ki, işletme otel ve restoran müşterilerine verdiği hizmet garantisi içerisinde, ilaçladıkları tesiste tüm zararlılar yok olana kadar hiçbir ödeme talep etmeyeceklerini, hizmetten hiç memnun kalınmaz ise alınan hizmetlerden on iki aya kadar bir geri ödeme alınabileceğini, bir müşterinin tesiste bir haşere görmesi halinde, müşterinin yemeğini veya odasını ödeyeceklerini ve bir özür mektubu göndererek, gelecekteki bir yemek veya konaklama için ödeme yapacaklarını, böcek veya kemirgen varlığından dolayı tesisin kapatılması halinde, tüm para cezalarının yanı sıra, tüm kayıp karların üzerine ilave 5.000 ABD Doları ödeyeceklerini ifade etmektedir. Özetle işletme, müşterisine "sizi \%100 memnun edemez isek, paranızı almiyoruz" demektedir (Hart, 1988).

Benzer bir şekilde ABD'de kurulmuş bir spor merkezi, beden eğitimi, spor ve atletik performansı artıran yenilikçi, yüksek kaliteli ve dayanıklı ürünler sunarken, koşulsuz olarak yüzde yüz memnuniyet garantisi ile sundukları tüm ürünlerinin arkasında olduklarını ve herhangi bir nedenle alınan hizmetten memnun kalınmaması halinde, istenildiği zaman kendileriyle iletişime geçilerek; ürünün değiştirilebileceğini, ödenen bedelin hesaba iade edileceğini ve bütün bunlar için de hiçbir şey talep edilmeyeceğini ifade etmektedirler (Moving Minds, 2019).

Konaklama sektöründe uluslararası zincir konumunda olan bir otel işletmesinde ise amaçlarının müşterilerinin otelde kaldıkları sürece tam olarak tatmin edilmesi olduğu, kalış sürelerinin herhangi bir anında kendilerine sunulan hizmetten tatmin olmamaları halinde yetkililerin bilgilendirilebileceği ve onların da sorunu çözememesi halinde de kalınan süreye 
ait otel bedelinin alınmayacağı ve işletmelerinin yüzde yüz tam bir müşteri memnuniyeti ya da ücret iadesini garanti ettiğini ifade etmektedir (Bowie ve Buttle, 2004, s.286-287).

İngiltere merkezli bir laboratuvar test cihazları satış ve satış sonrası servis hizmetini yapan bir işletmede de benzer şekilde, kesintisiz ve mükemmel satış sonrası servis, müşteri taleplerine ve sipariş teslim sürelerine hızlı cevap verme ve üründen ya da hizmetten memnun kalınmaması halinde de koşulsuz müşteri memnuniyeti garantisi sunulmaktadır (Elodiz, 2019).

Wal-Mart mağazaları koşulsuz müşteri memnuniyeti konusunda uluslararası alanda bilinen en önemli örneklerden birisidir. 1962 yılında kuruluşundan itibaren elli yıl içerisinde 8.500 'den fazla zincir mağazası ile ABD'nin ve dünyanın en büyük perakende zinciri olan $\mathrm{ABD}$ merkezli Wal-Mart mağazaları, kurucusu Sam Walton tarafından icat edilen bir yönetim felsefesi olan "Her gün En Düşük Fiyat" sloganı ve bir tüketici memnuniyetsizliği durumunda iade edilen herhangi bir ürünün (yarısı tüketilmiş hazır kahve tozunun bile) koşulsuz olarak değiştirilmesi ilkesini benimsemesi ile tanınmıştır (Huang ve Jia, 2015, s.11; Yokohoma, 2019). WalMart mağazalarından herhangi bir ürün satın alan müşteri, ürünü istediği zaman iade edebilmekte ve daha önce yapmış olduğu ödemeyi geri alabilmektedir. Ürün iade departmanı, gıda maddelerinden dayanıklı tüketim maddelerine ve tekstile kadar satışını yaptığı binlerce ürünün iadesi sırasında herhangi koşul ileri sürmediği gibi, müşterisine de kendilerine açıklama yapması şartını koşmamaktadır. Bu haliyle işletmenin, dünyada koşulsuz müşteri memnuniyeti kavramını, mümkün olabilecek en geniş şekilde uygulayan bir işletme olduğunu söylemek mümkündür.

\section{Türkiye'de Koşulsuz Müşteri Memnuniyeti Uygulamalarn}

Ekonomik ve teknolojik olarak hızla gelişen ve büyüyen dünyamızda, müşteri ihtiyaçlarının doğru tanımlanması ve bu ihtiyaçlara doğru zamanda ve doğru şekilde cevap verilmesi, işletmeler için geçmişe kıyasla günümüzde daha da önem kazanan zorunlu bir unsurdur. Bu ihtiyaçlara verilen cevapların satış ile birlikte sona ermemesi ise geçmiş dönemlere göre yönetim politikalarının önemli bir evrimidir. 
Küreselleşme ile birlikte artan rekabet ortamı, Türkiye'de faaliyet gösteren işletmeleri de aynı pazar şartlarında rekabet etmeye zorlamaktadır. $\mathrm{Bu}$ bağlamda küresel işletmelerin uygulamakta oldukları müşteri odaklı pazarlama stratejilerinden, koşulsuz müşteri memnuniyetine evrilen süreçler, Türkiye'deki işletmeler tarafından da benimsenmeye başlanmıştır. $\mathrm{Bu}$ konuda Türkiye pazarının ilklerinden olduğu kabul edilen Beymen Mağazaları, "Koşulsuz Müşteri Mutluluğu" kapsamında özel siparişler, ömür boyu ücretsiz tadilat, hediye danışmanlığı, kurumsal hediye, randevulu alışveriş servisi, ev ve işyerine servis, ürün değişimi ve iadesi, ücretsiz eve teslim, yabancı ziyaretçi, son dakika hizmeti gibi uygulamaların yanı sıra dünyaca ünlü markaların tasarımcıları ile tanışma, moda haftalarına katılım ve özel ürün tedariki gibi alışverişin ötesinde çeşitli uygulamalar sunmaktadır (Beymen, 2019). Bir başka perakende satış alanı olan e-ticaret işletmelerinde de koşulsuz müşteri memnuniyetinin önemini arttırdığı, satış ve satış sonrası süreçlerde tüketiciye en iyi hizmeti sunan işletmelerin öne çıktığı görülmektedir. Bilişim sektöründe faaliyette bulunan, ürün ve satış sonrası sağladığı güvenli hizmetlerle müşterilerine kaliteyi sunan ve teknoloji perakendeciliğinin öncü işletmeleri arasında ifade edilen bir işletmede de benzer şekilde koşulsuz müşteri memnuniyeti sayesinde büyümenin gerçekleştirildiği ve bir önceki yıla göre \%30 büyüyerek, işletmenin hacminin 130 milyon liraya yükseltildiği belirtilmekte, hızlı büyümelerinin altında yatan sebebin koşulsuz müşteri memnuniyeti olduğu ifade edilmektedir (Akın, 2018). Ayrıca işletme, kaliteli hizmet anlayışının yanında müşterileri tarafından alınan ürünlerde bir problem ile karşılaşıldığ 1 takdirde, koşulsuz müşteri memnuniyeti politikaları gereğince, müşterilerinin sıkıntılarını gidermek üzere her türlü hizmetin sunulduğunu da ifade etmektedir.

Türkiye'de koşulsuz müşteri memnuniyeti ya da koşulsuz memnuniyet garantisi gibi uygulamaların, uluslararası alanda örnek olarak ifade edilen yukarıdaki işletmelerde olduğu gibi sınırsız şekilde uygulandığına çok rastlanılmamaktadır. Koşulsuz müşteri memnuniyetini uyguladıklarını iddia eden işletmeler, Beymen Mağazaları örneğinde olduğu gibi, koşulsuz iade garantisi gibi kendilerine önemli maliyet yükü oluşturabilecek uygulamalardan ziyade, müşterilerinin memnuniyet düzeyini arttıracak bedelsiz ek hizmetler yaratma çabasında olmaktadırlar. 
Türkiye'de tüketicinin üründen veya hizmetten memnun kalmaması halinde haklarının korunmasına ilişkin yasal düzenlemeler, Avrupa Birliği Müktesebatına uyumlaştırma sürecinde ele alınmış ve çeşitli değişikliklerle birlikte, 6502 Sayılı Tüketicinin Korunması Hakkında Kanun ve ilgili mevzuatı başlığı altında bugüne gelmiştir. Bu kapsamda özellikle 7.7.1999 tarihinde yürürlüğe giren ve birliğe dahil üye ülkeler tarafından 1.1.2001 tarihine kadar ulusal mevzuatlara aktarılması zorunluluğu bulunan 1999/44 sayılı AB Yönerge'si, Tüketicinin Korunması Hukuku alanında günümüze kadar çıkartılmış en önemli yönergelerden birisidir. Yönerge ile satıma konu tüketim malının sözleşmeye aykırı olması halinde, alıcı-tüketici lehine belli bir sıra ilişkisi içerisinde, ayıba karşı tekeffülden doğan dört seçimlik hak tanınmaktadır. İlk sırada alıcı-tüketicinin yapacağı seçime göre, ayıbın bedelsiz giderilmesini talep ve yine bedelsiz olmak üzere yenisiyle değiştirilmesini, diğer bir ifadeyle ayıpsız olanının teslimini talep hakları oluşturur. İkinci grupta ise, tıpkı satım hukukundaki ayıp nedeniyle dönme hakkında olduğu gibi, alıcı-tüketicinin sözleşmeden kurtulmayı talep etme ile son olarak, satım bedelinde indirim yapılmasını talep hakları bulunmaktadır (Demir, 2005, s.26,30-31).

Birçok işletmenin müşteri memnuniyeti kapsamında ifade ettiği ürün iadeleri, aslında belirli koşullar altında ve genellikle de 1999/44 sayılı AB Yönerge'si esas alınarak hazırlanmış olan 6502 Sayılı Tüketicinin Korunması Hakkında Kanun'un çizmiş olduğu sınırları çok da genişletmeyen müeyyide ve uygulama esasları kapsamında gerçekleşmektedir. Benzer şekilde e-ticaret siteleri tarafından yapılan satışlar çerçevesinde gerçekleşen ürün iadeleri de ilgili kanun kapsamında zorunlu olarak yapılmaktadır. Müşteri memnuniyeti odaklı dayanıklı tüketim malı üretim ve satışını gerçekleştiren işletmelerde de durum çok farklı değildir. Örneğin satın almış olduğunuz bir televizyonun değişimi için, ürünün performansından memnun olmamanız tek başına geçerli bir neden olmamakta, üretim hatasından kaynaklanan bir kusur olması ya da yasal garanti süresi içerisinde arızasının giderilememesi gibi koşulların gerçekleşmesi gerekmektedir. Bu koşulların gerçekleşmiş olması bile çoğu zaman "kullanıcı hatası" gibi, uluslararası alanda uygulanmakta olan koşulsuz müşteri memnuniyetinde ifadesi mümkün olmayan gerekçelerle yeterli kabul edilmemekte ve tüketicilerin mağduriyeti ile sonuçlanmaktadır. Tüketicilere ise 
ilgili kanunlar kapsamında şikâyette bulunmak ya da dava açmak, mağduriyetlerini giderme noktasında tek yol olarak görülmektedir.

\section{Koşulsuz Müşteri Memnuniyeti Kapsamında Ortaya Çıkan Maliyetler}

Koşulsuz müşteri memnuniyeti uygulamalarından kaynaklanan maliyetleri, sadece müşterinin sorgulanmaksızın iadelerini kabul etme ve yenisi ile değişim ya da bedelini iade etme olarak görmek yanıltıcı olacaktır. Çünkü iade, değişim ya da tamir hizmetleri, Türkiye de dahil olmak üzere birçok ürünün ulusal ve uluslararası olarak sağladığı, yukarıda da yasal dayanağı olarak ifade edilen ürün garantileri kapsamında bulunmaktadır ve ilgili ülkelerdeki yasalar tarafından da güvence altına alınmıştır. Ancak koşulsuz müşteri memnuniyeti, yasal olarak sağlanan garantileri genişleten ve bazı durumlarda ömür boyu garanti olarak, bazı durumlarda ise belirli bir süre içerisinde kullanımından memnun kalınmama nedeniyle koşulsuz iade edebilmeyi içeren, kapsam olarak daha geniş bir uygulama şeklinde karşımıza çıkmaktadır. Ayrıca müşterinin ürün konusundaki memnuniyetini arttırabilmeye yönelik tüm çabalar da bu kapsama dahil olmaktadır. Bu nedenle koşulsuz müşteri memnuniyeti uygulama maliyetleri de uygulamayı yapan işletmelerin yönetim anlayışı ve pazarlama stratejilerine göre çeşitlenebilmektedir.

Koşulsuz müşteri memnuniyeti uygulamaları nedeniyle ortaya çıabilecek maliyetleri, satılan mal ve hizmetin özelliklerine bağlı olmakla birlikte, genel olarak aşağıdaki şekilde sıralamak mümkündür;

- Garanti kapsamında ürün değiştirme ve iade hizmeti,

- Koşulsuz ürün değiştirme ve iade hizmeti,

- Müşteri isteğine göre ürün üzerinde ücretsiz düzeltme hizmeti,

- Onarım ve parça değişim hizmeti,

- Ücretsiz kargo gönderim ve iade hizmeti,

- Ücretsiz müşteri şehir içi servis hizmeti,

- Ücretsiz montaj hizmeti,

- Ücretsiz yerinde ölçüm, dizayn ve modelleme hizmeti,

- Ücretsiz danışmanlık hizmeti,

- Müşteri memnuniyeti takibine ilişkin yazılım veya kiralama bedeli,

- Müşteri memnuniyetine ilişkin personel eğitim bedeli,

- Müşteri memnuniyeti bölümü kurulum ve faaliyet maliyeti. 
Yukarıda ifade edilen maliyetlerin bir kısmı ürün ve hizmetin satışı öncesi gerçekleşirken, büyük bir kısmı da satış sonrası olarak gerçekleşmektedir. Satış öncesi gerçekleşen ya da tahakkuk eden maliyet unsurlarının, genel kabul görmüş muhasebe ilke ve esasları çerçevesinde dönem giderleri içerisinde mi, ürün veya hizmetin maliyeti içerisinde mi muhasebeleştirilmesi gerektiği, cevaplanması gereken ilk sorudur. Buna karşılık, dönem gideri olarak kabul edilen harcamaların, fonksiyon esasına göre hangi gider hesabında izlenmesi gerektiği ise ikinci soru olarak karşımıza çıkmaktadır.

Tekdüzen hesap planı pazarlama satış ve dağıtım giderlerini, mamulün stoklara verildiği ve hizmetin tamamlandığ andan itibaren bu mal ve hizmetlerin alıcilara teslimine kadar yapılan giderler olarak tanımlamaktadır. Buna mukabil ücretsiz danışmanlık hizmeti, müşteri memnuniyeti takibine ilişkin yazılım, müşteri memnuniyetine ilişkin personel eğitimi, müşteri memnuniyeti bölümü kurulum ve faaliyeti, kargo gönderim ve iade hizmeti, müşteri şehir içi servis hizmeti gibi unsurlardan kaynaklanan harcamalar da bu kapsamda değerlendirilebilir. Ancak; garanti kapsamında ürün değiştirme ve iade hizmeti, koşulsuz ürün değiştirme ve iade hizmeti, onarım ve parça değişim hizmeti gibi, daha çok garanti yükümlülüğü kapsamında değerlendirilen hizmetlerden kaynaklanan ve dönemsel harcamaların hangi fonksiyonel gider hesabında izlenmesi gerektiğine ilişkin tereddütler yaşanabilmektedir. Diğer taraftan pazarlama satış ve dağıtım gider tanımında; alıcıya teslim ifadesi, sorumluluğun tamamlanması şeklinde yorumlanmalıdır. Bu bağlamda sorumluluğun belirli bir süre için mal ve hizmete bağlı bazı taahhütleri içermesi halinde, bu yükümlülükler açısından teslimin sürenin bitiminde tamamlanmış olacağı kabul edilerek, garanti kapsamındaki giderlerin, satış giderlerinin bir parçasını oluşturduğunu kabul etmek makul olacak ve bu nedenle de garanti kapsamındaki giderlerin, muhasebeleştirme sırasında satış giderleri ile ilişkilendirilmesi gerekecektir (Anasız, 2009, s.226). 


\section{Koşulsuz Müşteri Memnuniyeti Maliyetlerinin TMS/TFRS Açısından Değerlendirilmesi}

Koşulsuz müşteri memnuniyeti hizmetlerinden kaynaklanan harcamalar dönem gideri mi ürün veya hizmet maliyeti mi olmalı? Bu sorunu cevabı TMS 2 Stoklar Standardındaki hükümlere bakılarak cevaplanabilir. Standardın "Stokların Ölçümü" başlığı altında yer alan 15. paragrafında, "özel müşteriler için ürünlerin tasarlanmasına ilişkin maliyetlerin, stokların maliyetine dâhil edilmesi uygun olabilir" şeklinde bir ifade kullanılmakta ve bu maliyetlerin "diğer maliyetler" unsuru olduğu kabul edilmektedir (KGK, 2019c). Buna göre örneğin, müşteri isteğine göre ürün üzerinde ücretsiz düzeltme hizmetinden kaynaklanan harcamalar, ürünün maliyet unsuru olarak kabul edilebilir. Benzer şekilde ücretsiz montaj hizmetinden kaynaklanan harcamaların da aynı işleme tabi tutulması beklenir. Ancak yukarıda ifade edilen diğer birçok maliyet unsurunun, işlemin pazarlama ya da dağıtım fonksiyonu içermesi nedeniyle dönem giderleri içerisinde muhasebeleştirilmesi söz konusu olacaktır.

Koşulsuz müşteri memnuniyeti hizmetlerinden kaynaklanan harcamaların, gerçekleştiği dönem ile ilgili olduğu mal veya hizmetin satışının gerçekleştiği dönemlerin birbirlerinden farklı olması sıklıkla karşılaşılan bir durumdur. Bu durum özellikle yukarıda garanti kapsamında ifade edilen hizmetlere karşılık yapılan harcamalarda karşımıza çıkmaktadır. Ayrıca söz konusu giderler, ilgili olduğu ürün ya da hizmetin satışının yapıldığ 1 dönemde, genellikle ne tutarda gerçekleşeceği konusunda belirsizlik barındırmaktadır. Bu bağlamda konunun, müşterilere verilen garanti türünü de dikkate alarak, TMS 37 Karşılıklar, Koşullu Borçlar ve Koşullu Varlıklar Standardı ve TFRS 15 Müşteri Sözleşmelerinden Hasılat Standartları esas alınarak çözümlenebileceğini söylemek mümkündür (Saban vd, 2019, s.50).

Gerçekleşme zamanı ve tutarına ilişkin olarak bünyesinde önemli oranda belirsizlik barındıran garanti kapsamındaki hizmet harcamalar1nın, ilgili olduğu ürün ya da hizmetin satışının gerçekleştiği dönem ile ilişkilendirilmiş olması, dönemsellik ilkesinin de bir gereğidir. Bunu yapabilmek için ise söz konusu harcamaların ilgili ürün ve hizmet için ne kadar gerçekleşeceğinin tahmini ve bu amaçla karşılık ayrılması gerek- 
mektedir. TMS 37, gerçekleşme zamanı veya tutarı belli olmayan yükümlülükleri karşılık olarak tanımlamaktadır. Standart, burada ifade edilen yükümlülüğün, geçmiş olaylardan kaynaklanan ve ifası halinde ekonomik fayda içeren kaynakların işletmeden çıkmasına neden olacak mevcut yükümlülük olduğunu ifade etmektedir (KGK, 2019c). Bu bağlamda karşllık ayrılabilmesi için, yükümlülüğün geçmiş olaylardan kaynaklanmış olması gerektiği sonucu çıkmaktadır. TMS 37'nin 10. paragrafı yükümlülüğü; hukuki, zımni kabulden doğan ve koşullu olmak üzere üçlü sınıflamaya tabi tutmaktadır. Buna göre hukuki yükümlülük; sözleşme, yasal düzenleme ve diğer kanuni uygulamalardan doğmaktadır. Bu çerçevede koşulsuz müşteri memnuniyeti kapsamındaki hizmetlerini 6502 Sayılı Kanun sınırlamaları içerisinde tutan işletmelerin, kanuni yükümlülük çerçevesinde uygulama yaptıklarını söylemek mümkündür. Standardın söz konusu paragrafında, zımni kabulden doğan yükümlülükler ise işletmenin geçmişteki uygulamalar, yayımlanmış politikalar veya yeterince belirli cari açıklamalarla, işletmenin belirli sorumlulukları üstleneceğini diğer şahıslara taahhüt etmesi ve bunun sonucunda, işletmenin bu sorumlulukları yerine getireceği konusunda diğer şahıslar nezdinde geçerli bir beklenti yaratmış olması fiillerinden kaynaklanan yükümlülükler olarak tanımlanmaktadır. Dolayısıyla daha önce ifade edilen Wal-Mart işletmesi örneğinde olduğu gibi, her ortamda sınırsız ürün iade garantisi uyguladığını deklare etmiş olan bir işletme için değişim yükümlülüğü, zımni kabulden doğan bir yükümlülük olarak kabul edilmelidir.

Koşulsuz müşteri memnuniyeti kapsamında ve yukarıda ifade edilen şekilde doğan çeşitli yükümlülükler nedeniyle gerçekleşebileceği beklenen hizmetlere ilişkin karşılıkların hesaplanma esasları, TMS 37'nin 39. paragrafında tanımlanmıştır. Buna göre, karşılık olarak finansal tablolara yansıtılacak tutara ilişkin belirsizlikler, koşullara bağlı olarak farklı araçlarla ele alınabilir. Değerleme konusu karşılığın çok sayıda kalemden oluştuğu durumda, ilgili yükümlülük her türlü getiriyi bunlara ilişkin olasılıklara göre ağırlıklandırmak suretiyle tahmin edilir. Söz konusu istatistiksel tahmin metodunun ismi, "beklenen değer"dir (KGK, 2019c). Örneğin satılan bir ürünle ilgili bir yıllık bir garanti veren bir işletme, öncelikle geçmiş yıl verilerine bakarak ve istatistiksel olarak küçük ve büyük onarım için gider tutarlarını tahmin ettikten sonra, bunların gerçekleşme olasılığını hesaplayacaktır. Dolayısıyla gider büyüklüklerinin gerçekleşme 
olasılıklarının çarpımlarından elde edilecek toplam tutar, ayrılacak karşılık tutarı olacak ve bu tutar her yıl yapılacak benzeri çalışmalar ile güncellenecektir.

Uluslararası uygulamalar içerisinde yüzde yüz koşulsuz müşteri memnuniyeti garantisi uygulayan işletmelerde, fiyat içerisinde ne kadarlık kısmin bu garantiler nedeniyle bir marj olarak tutulduğu ve aslında gerçek fiyatın ne olduğu konusunda bir belirleme yapmak mümkün olmamaktadır. Özellikle Wal-Mart gibi büyük zincirlerin, söz konusu değişim garantisinden kaynaklanan maliyetin büyük bir kısmını tedarikçilere yüklemesi de mümkündür. Bunun dışında yarattığı güven ve garanti dolayısıyla ulaştığı büyük ölçek ekonomisi de düşünüldüğünde, aslında iadelerin hasılata kıyasla önemli oranda olmadığı da söylenebilir. Ancak Türkiye'de özellikle büyük perakende zincirlerinde benzer ölçek ekonomisi gerçekleşmemektedir. Dolayısıyla bu işletmeler ne kadar isteseler de garanti kapsamındaki hizmetlerini, yasal zorunlulukları çok fazla genişletmeyecek şekilde gerçekleştirmektedirler. Örneğin e-ticaret sitelerinde ya da fiziksel olarak mağazalardan yapılan alışverişlerde, müşterinin memnun olmama gerekçesinin söz konusu olduğu durumlarda da yasal garanti kapsamında sayılan gerekçelerdekine benzer şekilde, işletmeler tarafından garanti süresi çok uzun tutulmamakta, kısa değişim süreleri içerisinde de kullanılmamış ve yeniden satılabilmesi için de zarar görmemiş olma gibi kısitlar getirilmektedir.

Son zamanlarda yaygınlaşmaya başlayan bir diğer uygulama ise özellikle dayanıklı tüketim mallarında müşteriye uzatılmış garanti süreleri önerilmesi ve bu ek süreler için de bir bedel alınmasıdır. Bu durumda garanti kapsamında satışı yapılan ürün ve hizmetlerden elde edilen hasılatın muhasebeleştirilmesi ayrı bir öneme sahip olacaktır. TFRS 15' in "Garantiler" başlığı altında bulunan B28, B29 ve B30 paragrafları bu konuya açıklık getirmektedir.

TFRS 15, garantilerin niteliği, sektörlere ve sözleşmelere bağlı olarak önemli ölçüde değişebilmekle birlikte bazılarının, üzerinde anlaşılan özelliklere uygun olarak ilgili ürünün, tarafların amaçladığı işlevi yerine getireceğine dair müşteriye teminat verdiğini, diğer garantilerin ise ürünün üzerinde anlaşılan özelliklere uygun olduğuna dair müşteriye verilen teminata ilave olarak müşteriye bir hizmet sağladığını ifade etmektedir (TFRS 15, B28). Bu bağlamda müşterinin garantiyi ayrı olarak satın alma 
opsiyonuna sahip olması durumunda garantinin farklı bir hizmet olarak değerlendirilmesini, çünkü işletmenin sözleşmede belirtilen işlevlere sahip olan ürüne ilave olarak, bu ek garanti hizmetini müşteriye sunmayı taahhüt ettiğini, bu nedenle de işletmenin taahhüt ettiği garantiyi standardın 22-30 paragrafları uyarınca edim yükümlülüğü olarak muhasebeleştirilip, işlem bedelinin bir kısmının da 73-86 paragrafları uyarınca bu edim yükümlülüğüne dağıtılmasını istemektedir (TFRS 15, B29). Uygulamada ek garanti için satılan ürün veya hizmetlerde ayrı bir fiyatlandırmanın yapıldığ 1 ve müşteriye de bunun açıkça bildirilerek onayının alınmasından sonra faturalandığı görülmektedir.

Müşterinin garantiyi ayrı olarak satın alma opsiyonuna sahip olmaması halinde, bir başka ifadeyle ek bir garanti yükümlülüğü ile birlikte satıcı işletme tarafından buna ilişkin açık bir bedel istenmediği durumlarda, yukarıda da açıklanan TMS 37 uyarınca muhasebeleştirilmesi uygun bulunmaktadır (TFRS 15, B30). Türkiye'de 6502 Sayılı Kanun çerçevesinde düzenlenmesi zorunlu garanti belgesi kapsamında işletmeler tarafından verilmesi zorunlu olan hizmetler, bu kapsamda değerlendirilerek muhasebe uygulaması gerçekleştirilmelidir.

\section{Sonuç}

Koşulsuz müşteri memnuniyetini küreselleşen ekonomilerde faaliyet gösteren işletmelerde, değişim garantisinin genişletilmiş bir hali ve değişik hizmetlerin verilmesini içeren bir pazarlama ve yönetim stratejisi olarak görmek, kavramın işletmelerdeki fonksiyonunu tanımlamak açısından eksik kalacaktır. Literatürde yer alan çalışmalar konuyu daha çok pazarlama açısından ele almaktadır. Ancak son yıllarda yapılan çalışmalar, koşulsuz müşteri memnuniyeti uygulamaları içerisinde gerçekleştirilen çeşitli hizmetlerin etkilerini, çok yönlü olarak düşünmemize imkân vermektedir. Bu bağlamda Knox ve Oest (2014, s.42), iki yılı aşan bir süre boyunca 20.000 yeni internet müşterisi ve perakendecisi üzerinde yapmış oldukları çalışmalarında, müşteri şikayetlerinin etkisinin sınırlı kaldığını, müşteri şikayetin ardından sistemde kaldığı ve kısa bir süre içinde yeni bir şikayete sebep olacak bir durum gerçekleşmediği takdirde, ilişkinin hızla normale döndüğünü, iyileştirme yönünde yapılan memnuniyeti arttıracak 
yönde çabaların şikayetin etkisini önlemekle birlikte, tamamen telafi edemediğini ortaya koymaktadırlar.

Çağımız pazarlama anlayışı olan tüketici odaklılık ve koşulsuz müşteri memnuniyeti hedefi gereği, tüketicilerin ihtiyaçlarının tam olarak karşılanabilmesi için tüketicilerin yaş, cinsiyet, eğitim, gelir durumu, kültür, alt kültür vb. özellikleri ve ürünlerin kullanıldıkları mekân, tür, fonksiyon, form, yapı, malzeme, büyüklük, dayanıklılık, güvenilirlik, estetik, emniyet, fiyat vb. özellikleri göz önünü alınarak pazar daha küçük alt bölümlere ayrılmaktadır (Öztürk vd., 2017, s.758). Tüm bu alt bölümler ile koşulsuz müşteri memnuniyeti uygulamalarının birbirlerine olan karşılıklı etkileri, daha çok pazarlama bilim alanı içerisinde tartışılması gereken konular arasındadır. Ancak söz konusu hizmetlerin, işletmelerin finansal performansları üzerindeki etkileri de son yıllarda artan bir ilgi alanı olmaktadır. Mittal vd., (2005, s.553), yaptıkları çalışmada bu etkileşimleri tespit ve ölçmeye çalışmışlardır. Çalışmalarında; yöneticiler için en uygun alt stratejinin maliyet azaltma ile birlikte müşteri memnuniyetini arttırmak olacağını, uzun vadeli finansal getiri artışının, her ikisini de başarılı bir şekilde elde eden firmalarda görülebildiğini, analize dahil ettikleri tipik bir banka için, ölçülen müşteri memnuniyetinde bir puanlık bir artış sonucunda bankanın piyasa değerinde, bankanın yüksek verimli olması halinde 1,61 milyar ABD Doları, düşük verimlilikte bir banka için ise 298 milyon ABD Doları ilave artış olduğu tespit edilmektedir.

Koşulsuz müşteri memnuniyeti kapsamında verilen hizmetlerin, bu hizmetleri veren işletmelerin finansal performansları üzerindeki etkilerini tespit etmek ve doğru olarak ölçebilmek, öncelikle muhasebe biliminin ilgi alanını oluşturmaktadır. Bu çalışmada söz konusu etkilerin doğru yansıtılabilmesi bağlamında, daha çok muhasebe uygulamalarında yapılması gereken işlemler, TMS'ler ve TFRS'ler kapsamında ele alınmıştır.

Koşulsuz müşteri memnuniyeti hizmetlerinden kaynaklanan harcamalar ilk olarak TMS 2'ye göre ele alındığında, müşteri isteğine göre ürün üzerinde ücretsiz düzeltme, ücretsiz montaj vb. hizmetlerinden kaynaklanan giderlerin, ürünün maliyet unsuru olarak kabul edilmesi uygun olacaktır.

Koşulsuz müşteri memnuniyeti hizmetlerinden kaynaklanan harcamaların gerçekleştiği dönem ile ilgili olduğu mal veya hizmetin satışının gerçekleştiği dönemlerin birbirlerinden farklı olması, söz konusu giderlerin 
muhasebeleştirilmesi sorunu, müşterilere verilen garanti türünü de dikkate alarak, TMS 37 ve TFRS 15 esas alınarak çözümlenmelidir. Dönemsellik ilkesinin gereği olarak, söz konusu harcamaların ilgili ürün ve hizmet için ne kadar gerçekleşeceğinin tahmini ve bu amaçla karşıllık ayrılması gerekmektedir. Buna göre koşulsuz müşteri memnuniyeti kapsamındaki hizmetlerini 6502 Sayılı Kanun sınırlamaları içerisinde tutan işletmeler, kanuni yükümlülük çerçevesinde uygulama yapmaktadırlar. Buna karşın sınırsız ürün iade garantisi uyguladığını deklare etmiş olan bir işletme için değişim yükümlülügü, zımni kabulden doğan bir yükümlülük olarak yerine getirilmektedir.

Koşulsuz müşteri memnuniyeti kapsamında doğan çeşitli yükümlülükler nedeniyle gerçekleşebileceği beklenen hizmetlere ilişkin karşılıklar, TMS 37 çerçevesinde "beklenen değer" olarak adlandırılan istatistiksel metot ile hesaplanmalıdır.

Son zamanlarda yaygınlaşmaya başlayan, özellikle de dayanıklı tüketim mallarında sıklıkla rastlanan uzatılmış garanti süreleri kapsamında satışı yapılan ürün ve hizmetlerden elde edilen hasılatın muhasebeleştirilmesi, TFRS 15'in "Garantiler" başlığı altında bulunan B28, B29 ve B30 paragrafları çerçevesinde işleme tabi tutulmalıdır. Bu bağlamda müşterinin garantiyi ayrı olarak satın alma opsiyonuna sahip olması durumunda, garantinin farklı bir hizmet olarak değerlendirilmesi, bu nedenle de işletmenin taahhüt ettiği garantiyi edim yükümlülüğü olarak muhasebeleştirilip, işlem bedelinin bir kısmının da bu edim yükümlülüğüne dağıtılması gerekmektedir. Müşterinin garantiyi ayrı olarak satın alma opsiyonuna sahip olmaması, başka bir ifadeyle Türkiye'de 6502 Sayılı Kanun çerçevesinde düzenlenmesi zorunlu garanti belgesi kapsamında işletmeler tarafından verilmesi zorunlu olan hizmetler söz konusu olması halinde, işlemlerin TMS 37 uyarınca muhasebeleştirilmesi uygun olacaktır.

Koşulsuz müşteri memnuniyeti kapsamında verilen hizmet giderlerinin takibi yanında, sebebini oluşturan ürün veya hizmetin satışının yapıldığı ilgili dönemlere dağıtılması, muhasebenin en temel ilkelerinden birisi olan "dönemsellik ilkesi"nin bir zorunluluğudur. Yukarıda ifade edilen standartlar kapsamında işlemlerin yapılmasına özen gösterilmediği takdirde, finansal tabloların dönemler arasında karşılaştırılabilir olması ilkesi zarar görecek ve işletmenin finansal performansının doğru olarak ölçümü 
mümkün olamayacaktır. Geçmiş yıllarda yaşanan muhasebe skandallarının etkileri de düşünülerek, işletmelerin gerçek faaliyet sonuçlarının ve finansal durumlarının önemi de dikkate alındığında, bu konuda hassasiyet gösterilmesi daha da önemli hale gelmektedir. Ayrıca son yıllarda işletmelerin pazarlama departmanlarının da ilgi alanına daha fazla giren, müşteri karlılığının tespiti ve uygulanan müşteri memnuniyeti çalışmalarının bu karlılık üzerindeki etkilerinin ölçümü açısından bakıldığında, ana veri kaynağı olan muhasebe tarafından üretilen bilgilerin doğru ve güvenilir olması, pazarlama ve satış yöneticileri için de vazgeçilmez bir unsur olmaktadır. 


\section{EXTENDED ABSTRACT}

\section{Evaluation of Unconditional Customer Satisfaction Practices in Terms of International Accounting/ Financial Reporting Standards (IAS / IFRS) \\ $*$ \\ Vedat Acar}

İzmir Bakırçay University

The dimensions of competition, one of the requirements of the global economy, are increasing rapidly. As a natural consequence of this situation, new tools are being developed by the business managers to replace the wars over the prices. Large enterprises that improve brand image and break price elasticity of demand need other satisfaction tools to put in front of their customers. While customers are directed to brands that are relatively expensive from their similar, relieving the problems that may arise in the future in a fast and desirable way can also significantly contribute to the efforts to increase sales. In case of any problems in the product that are not caused by the customer, the guarantee of change also plays an important role in enabling the customer to accept why he/she is purchasing an expensive product.

The dimensions of competition, one of the requirements of the global economy, are increasing rapidly. As a natural consequence of this situation, new tools are being developed by the business managers to replace the wars over the prices. Large enterprises that improve brand image and break price elasticity of demand need other satisfaction tools to put in front of their customers. While customers are directed to brands that are relatively expensive from their similar, relieving the problems that may arise in the future in a fast and desirable way can also significantly contribute to the efforts to increase sales. In case of any problems in the product that are not caused by the customer, the guarantee of change also plays an important role in enabling the customer to accept why he/she is purchasing an expensive product. 
Customer satisfaction, which can be expressed as answer the expectations of the customers, can be seen as sufficient to keep the current customers. However, unconditional customer satisfaction, which is a step beyond in the process of acquiring new customers, will be more effective.

The focus of today's enterprises is to provide an unconditional customer satisfaction, unlike the traditional point of view, which is the main objective of achieving maximum output by providing rationality and efficiency (Dogan and Demiral, 2007, p.283). Unlike unconditional customer satisfaction, customer orientation and CRM, it is required to give equal value to all customers without considering the contribution to the enterprise and to show the same sensitivity and satisfaction to the customer who wants to change the product even after years of use. An unconditional warranty to be covered in this context covers both the basic service offer (e.g. - a hotel room, a meal, a haircut) and the delivery of the service (e.g. - courteous, friendly providers). In this context, an increasing number of service businesses over the past few years have discovered that one of the most effective ways to influence customers' perceptions of reliability is to provide an unconditional satisfaction guarantee (McDougal, 1998, p.279).

The concept of unconditional customer satisfaction guarantee stands out that is used more than unconditional customer satisfaction in the international literature. In this context, one of the messages that an entity can forward to its customers is the unconditional satisfaction guarantee and the message that the statement contains; In the words of unconditional expression will not be asked for excuse or explanation, expressed as a statement of the customer's right to do or do not do the final judge is stated that the key points. In other words, an unconditional guarantee is a promise that an enterprise will meet the expectations of all its customers (Swartz and Lacobucci, 2000, p.305).

It can be assumed that an unconditional customer satisfaction guarantee dominated by a belief that it will not be possible for many business managers to be provided by the service industry. An unconditional customer satisfaction guarantee dominated by a belief that it will not be possible for many business executives to be employed in the service industry can be considered more useful for products. Examples that support this situation do not result in a guarantee of satisfaction for all services (Hart, 
1988). For instance, the guarantee offered by a US-based pest-extermination company; While many of its competitors claim that they will reduce pests to acceptable levels, the company promises to destroy them completely. Even the scope of this warranty is so broad that the company's service to the hotel and restaurant customers within the guarantee, no pests in the facility where they will not ask for any payment until the service, if it is not satisfied after the services completed a twelve-month refund can be received, if a customer sees a pest, the company will pay the customer's room and meal and send an apology letter, pay a future meal or accommodation, if the plant is shut down due to the presence of insect or rodent, the company will pay an additional 5.000 USD on all lost profits as well as all fines. In summary, the enterprise says, "if we cannot satisfy you $100 \%$, we do not take your money" (Hart, 1988).

Wal-Mart stores are one of the most important international recognized examples of unconditional customer satisfaction. A management philosophy invented by the US and the largest retail chain in the world, Wal-Mart stores, the founder Sam Walton, with more than 8,500 chain stores are known to slogan of "The Lowest Price Every Day" and adopt the principle of unconditional replacement of any item returned -even half-consumed instant coffee powder - if a consumer was dissatisfied (Huang and Jia, 2015, p.11; Yokohoma, 2019).

Globalization and increasing competition force the Turkish companies to compete in the same market conditions. In this context, the customeroriented marketing strategies that have implemented by the global business, evolved to the customer satisfaction and began to be adopted by enterprises in Turkey. Beymen stores are considered to be the first, "Unconditional Customer Satisfaction" implementation in this regard for Turkish retail chain. Under the Unconditional Customer Satisfaction principles, special orders, lifetime free modification, gift consulting, corporate gifts, appointments shopping service, shuttle service to homes and businesses, product changes and refunds, free home delivery, foreign as well as applications such as visitors, last-minute services, meeting with the designers of world-famous brands, participation in fashion weeks and special product supply are applied by Beymen Store (Beymen, 2019).

Unconditional customer satisfaction or unconditional satisfaction guarantee applications, such as the above mentioned in the international 
practices is not seen as unlimited in Turkey. Enterprises that claiming to apply unconditional customer satisfaction, like the Beymen Stores, avoid the applications that can create significant cost burden such as unconditional return guarantee. Rather, they are trying to create additional free services that will increase the satisfaction of their customers.

It will not be true to consider the costs of unconditional customer satisfaction practices as simply accepting the customer's return without any question and changing a new one or refund the its price. Unconditional customer satisfaction is a wider application that extends the legally guarantee and, in some cases, includes a life-long warranty and in some cases includes unconditional return due to their satisfaction with the use within a certain period of time.

Although the cost of unconditional customer satisfaction depends on the characteristics of the goods and services sold, it is generally possible to list as follows;

- Product service of replacement and return warranty,

- Service of Unconditional product replacement and return,

- Service of free correction on product according to customer request,

- Service of repair and replacement,

- Service of free shipping and return,

- Service of free customer transportation,

- Free installation service,

- Free on-site measurement, design and modeling service,

- Free consultation,

- Software purchase or rental price related to customer satisfaction tracking,

- Personnel training cost related to customer satisfaction,

- Installation and operating cost of customer satisfaction department

Some of the costs mentioned above are occurred before the sale of products and services, while most of them are realized after sales. It is an important issue that the cost elements that are realized or incurred before the sales what expenditures should be recorded in the period expenses or in the cost of the product or service according to the generally accepted 
accounting principles. On the other hand, the other important issue is what expenses should be tracked based on function.

The uniform chart of accounts defines the marketing sales and distribution expenses as the expenses incurred until the delivery of the goods and services to the buyers or the warehouse and the service is completed. On the other hand, expenditures arising from the elements that free consultancy service, customer satisfaction tracking software, customer satisfaction personnel training, customer satisfaction department installation and activity, delivery and return service, customer transportation service, can be evaluated in that framework. But, within the scope of the warranty, there may be hesitations about which functional expenses should be tracked in the periodic expenses arising from the services evaluated within the scope of guarantee obligation, such as product replacement and return service.

Should the expenses incurred from unconditional customer satisfaction services be the period expense or cost of product or service rendered cost? This question can be answered by looking at the standard of IAS 2 Inventories. In the 15th paragraph of the standard, the statement to measurement of inventories state that costs related to the design of products for private customers may be appropriate to be included in the cost of inventories and these costs are considered to be other costs (KGK, 2019c). Accordingly, the costs incurred by the free customization service on the product according to the customer's request can be considered as a cost element of the manufacturing. Similarly, expenditures arising from the free installation service are expected to be the same. However, many other cost elements mentioned above will be accounted for in the period expenses as the transaction includes the marketing or distribution function.

The period in which the expenses incurred from unconditional customer satisfaction services and the sale of goods or services may be different from each other. Therefore, the issue of accounting for such expenses should be solved based on TAS 37 and TFRS 15, taking into account the type of guarantee granted to customers. Therefore, the issue of accounting for such expenses should be solved based on IAS 37 and IFRS 15, depending on the type of warranty granted to customers. As a requirement of the principle of periodicity, it is necessary to estimate how much these ex- 
penses will be incurred for the relevant product and service and to provide a provision for this purpose. According to this statement, enterprises holding unconditional customer satisfaction services within the limits of Law Code 6502 do their practices within the framework of legal obligations. However, the obligation to change for an enterprise that declared unlimited product return guarantee is fulfilled as an implied obligation. Therefore, as in the case of the previously mentioned Wal-Mart business, the obligation to exchange for an enterprise that declares unlimited product return guarantees in any environment must be accepted as a implied obligation.

The recognition of revenue from products and services sold within the scope of extended warranty periods, which are becoming widespread in recent times, especially in durable consumer goods, should be made in accordance with paragraphs B28, B29 and B30 of TFRS 15, subject to the scope of Guarantees. In this context, if the customer has the option to purchase the guarantee separately, the warranty should be considered as a different service and therefore the guarantee committed by the entity is accounted for as a performance obligation and a part of the transaction price must be distributed to this performance obligation. If the customer does not have the option to purchase the warrant separately, in other words, if the services are obligatory within the scope of the mandatory warranty certificate, it will be appropriate to recognize the transactions in accordance with IAS 37.

In addition to track of service expenses within the scope of unconditional customer satisfaction, the distribution of the products or services constituting the reason of these expenses to the relevant periods of sale is a requirement of periodicity assumption which is one of the most basic principles of accounting. Unless the Company's attention is paid to the mentioned standards above, the principle of comparability of the financial statements between the comparative periods will be impaired and the financial performance of the entity will not be measured accurately. Considering the effects of accounting scandals in previous years, it is becoming more and more important to show the real activity results and financial conditions of the enterprises. In addition, in recent years, the determination of customer profitability and the effects of applications of customer satisfaction studies on this profitability have started to enter the interest 
of the marketing departments of enterprises. From this perspective, the accurate and reliable information source produced by the accounting is an indispensable element for the marketing and sales managements.

\section{Kaynakça / References}

Akın, E. (2018, 27 Eylül). Koşulsuz müşteri memnuniyeti ile hızlı büyüyorlar. Habertürk, 10.03.2019 tarihinde https://www.haberturk.com/kosulsuz-musteri-memnuniyeti-ile-hizli-buyuyorlar2158303-ekonomi\# adresinden erişilmiştir.

Alnıaçı, Ü. ve Özbek, V. (2009). Otobüs işletmelerinde hizmet kalitesinin ölçümü: Kandıra Gürkan Turizm örneği, International Journal Of Economic and Administrative Studies, 2(3), 125-137.

Alomaim, N., Tunca, M. Z., Zairi, M. (2003). Customer satisfaction@virtual organizations. Management Decision, 41(7), 666-670.

Anasız, İ. (2009). TMS ve TFRS açısından garanti maliyetlerinin muhasebeleştirilmesi ve maliyet analizlerine etkileri. E-journal of New World Sciences Academy, 4(3), 224-240.

Beymen (2019). Koşulsuz müşteri mutluluğu. 08.04.2019 tarihinde https://www.beymen.com/content/ kosulsuz-musteri-mutlulugu, adresinden erişilmiştir.

Bowie, D. ve Buttle, F. (2004). Hospitality marketing, Heinemann:Elsevier Butteworth.

Demir, M. (2005). Tüketim mallarının satımındaki garantilere ilişkin ab yönergesi ve ülkemizdeki yasal düzenleme. Ankara Üniversitesi Hukuk Fakültesi Dergisi, 54(3), 23-51.

Doğan, S. ve Demiral, Ö. (2007). İşletmelerde personel güçlendirme kültürünün yaratılmasıyla müşteri memnuniyetinin sağlanması, Selçuk Üniversitesi Karaman İ.I.B.F. Dergisi, 12(9), 282-303.

Elodiz (2019). Customer satisfaction. 09.03.2019 tarihinde https://www.elodiz.com/ chromatography adresinden erişilmiştir.

Gürsakal, N. (2005). Altı sigma müşteri odaklı yönetim, Ankara: Nobel Yayın Dağıtım.

Hart, C. W. (1988). The power of unconditional service guarantees. 14.03.2019 tarihinde https://hbr.org/1988/07/the-power-of-unconditional-service-guarantees_adresinden erişilmiştir. 
Homburg, C., Droll, M. ve Totzek, D. (2008). Does it pay off, and how should it be implemented?, Journal Of Marketing, 72(5), 110-130.

Huang, J., ve JIA, Y. (2015). Wal-Mart development in Chinese market: problem and countermeasures-nased on the enterprise culture and ethics. International Business and Management, 10(2), 11-15.

Kamu Gözetim Kurumu (2019a). Kamu gözetim kurumu tanıtım broşürü. 02.03.2019 tarihinde http://kgk.gov.tr/portalv2uploads/files/pdf$\% 20$ linkleri/tan\%c4\%b1t\%c4\%b1m/public_oversight_authority_tr.pdf adresinden erişilmiştir.

Kamu Gözetim Kurumu (2019b). TMS/TFRS ve TMS/TFRS yorumları nedir? 07.03.2019 tarihinde http://kgk.gov.tr/dynamiccontent-detail/6651/tms/tfrs-ve-tms/tfrs-yorumlar\%c4\%b1-nedir?, adresinden erişilmiştir.

Kamu Gözetim Kurumu (2019/c). TMS/TFRS 2019 seti. 20.03 .2019 tarihinde http://kgk.gov.tr/dynamiccontentdetail/9182/tms/tfrs-2019seti adresinden erişilmiştir.

Knox, G. ve Oest, R. V. (2014). Customer complaints and recovery effectiveness: a customer base approach, Journal of Marketing, 78(5), 4257.

McDougal, G. H. G., Levesque, T. ve Vanderplaat, P. (1998). Designing the service guarantee: Unconditional or specific?, Journal Of Services Marketing, 12(4), 278-293.

Moving Mind (2019). Unconditional 100\% satisfaction guarantee. 09.03.2019 tarihinde https://www.moving-minds.com/about/unconditional100-satisfaction-guarantee adresinden erişilmiştir.

Mittal, V., Anderson, E. W., Sayrak, A. ve Tadıkamalla, P. (2005). Dual emphasis and the long-term financial impact of customer satisfaction, Marketing Science, 24(4), 544-555.

Mucuk, İ. (1999). Pazarlama ilkeleri. İstanbul: Türkmen Kitabevi.

Özilhan, D. (2010). Müşteri ilişkileri yönetimi (MIY) uygulamalarının işletme performansına Etkileri, Gümüşhane Üniversitesi Sosyal Bilimler Enstitüsü Elektronik Dergisi, 1(1), 18-30.

Özmen, U. (2019). Müşteri odaklllık nedir. 08.04.2019 tarihinde http://www.Uzaktancrmegitimi.com/4174/musteri-odaklilik-nedir adresinden erişilmiştir. 
Öztürk, Y., Yılmaz, K. ve Burdurlu, E. (2017). Veri madenciliği ile Türkiye mobilya sektörü için 2023 öngörüleri, İleri Teknoloji Bilimleri Dergisi, 6(3), 757-763.

Saban, M., Küçüker, M. ve Küçüker, H. (2019). Garantilerin muhasebe standartları çerçevesinde muhasebeleştirilmesi, Muhasebe Ve Finans İncelemeleri Dergisi, 2(1), 47-54.

Sakallı, H. (2007). Tekstil sektöründe lojistik ve tedarik zinciri yönetimi, yayımlanmamış yüksek lisans tezi, Dokuz Eylül Üniversitesi Sosyal Bilimler Enstitüsü, İzmir.

Swartz, T. A. ve Lacobucc1, D. (2000). Handbook of services marketing and management, USA: Sage Publications.

Şahin, S. ve Şen, Ö. (2017). Hizmet kalitesinin müşteri memnuniyeti üzerine etkisi, Uluslararası Sosyal Araştırmalar Dergisi, 10(52), 11771184.

Triest, S. V., Bun, M. J. G., Raaij, E. M. V. ve Vernooij, M. J. A. (2009). The impact of customer-specific marketing expenses on customer retention and customer profitability, Marketing Letters, 20(2), 125138.

Yokohoma, Y. (2019). Perspective on public sector management. 09.03.2019 tarihinde https://www.rieti.go.jp/en/columns/a010082.html?mode $=$ print adresinden erişilmiştir.

\section{Kaynakça Bilgisi / Citation Information}

Acar, V. (2019). Koşulsuz müşteri memnuniyeti uygulamalarının uluslararası muhasebe/finansal raporlama standartları (UMS /UFRS) açısından değerlendirilmesi. OPUS-Uluslararası Toplum Araştırmaları Dergisi, 12(18. UİK Özel Sayısı), 953-982. DOI: 10.26466/opus.584091 